\title{
What does immunology have to do with brain development and neuropsychiatric disorders?
}

\author{
James F. Leckman'1 ${ }^{1}$ Pedro G. de Alvarenga², Beatriz Ravagnani², Isaac N. S. Johnson ${ }^{1,3}$
}

Leckman JF, Alvarenda PG, Ravagnani B, Johnson INS. What does immunology have to do with brain development and neuropsychiatric disorders? Rev Med (São Paulo). 2019 July-Aug.;98(4):241-253.

\begin{abstract}
Introduction: Neural development is an enormously complex and dynamic process. From very early in brain development 'immune cells' play a key role in a number of processes including the formation and refinement of neural circuits, as well as sexual differentiation. There is a growing body of evidence that the immune system also plays an important role in the pathobiology of several neurodevelopmental and neuropsychiatric disorders. Objective: The goal of this article is to review the currently available data concerning the role of the 'immune system' in normal brain development, as well as its role in the pathobiology of neurodevelopmental and neuropsychiatric disorders. Methodology: We conducted a traditional literature search using PubMed and recent special issues of journals to locate relevant review articles. Results: The cellular and molecular processes that make up our 'immune system' are crucial to normal brain development and the formation and maintenance of neural circuits. It is also increasingly evident that the immune system and neuroinflammation play important roles in the pathobiology of at least a subset of individuals with Autism Spectrum Disorder (ASD), schizophrenia, obsessive-compulsive disorder, Tourette syndrome and mood disorders, such as depression, as well as autoimmune and neurodegenerative disorders. Emerging evidence also points to the importance of the 'gut-brain axis' and an individual's microbiome, which can impact an individual's somatic and mental well-being. Conclusions: There are multidirectional interconnections across multiple biological systems in our brains and bodies that are mediated in part by the immune system. At present, however, the 'promise' of this field remains greater than the 'deliverables'. Time will tell whether novel interventions will be developed that will make a positive difference in the care of our patients. It is also possible that valid biomarkers will emerge that will guide a more personalized approach to treatment.
\end{abstract}

Keywords: Immune system; Immunology; Neurodevelopmental disorders; Microglia; Immunity, maternally-acquired; Neuroimmunomodulation; Cytokines; Autistic disorder; Autism spectrum disorder; Schizophrenia; Obsessive-compulsive disorder; Tourette syndrome; Depression; Mood disorders; Stress, psychological.
RESUMO: Introdução: O desenvolvimento neural é um processo extremamente complexo e dinâmico. Tao pronto se inicia o desenvolvimento do cérebro, as "células imunológicas" desempenham um papel fundamental em vários processos, incluindo a formação e aperfeiçoamento de circuitos neurais, bem como a diferenciação sexual. Há um crescente corpo de evidências de que o sistema imunológico também desempenha um papel importante na fisiopatologia de diversos transtornos neurodesenvolvimentais e neuropsiquiátricos. Objetivo: O objetivo deste artigo é revisar os dados atualmente disponíveis sobre o papel do "sistema imunológico" em relação ao desenvolvimento normal do cérebro, bem como a fisiopatogenia dos transtornos de neurodesenvolvimento e neuropsiquiátricos. Metodologia: Foi realizada uma pesquisa bibliográfica tradicional para localizar artigos de revisão relevantes. Resultados: Os processos celulares e moleculares que compõem o nosso "sistema imunológico" são cruciais para o desenvolvimento normal do cérebro e a formação e manutenção de circuitos neurais. É cada vez mais evidente que o sistema imunológico e neuroinflamação desempenham papéis importantes na etiopatogenia de pelo menos um subconjunto de indivíduos com autismo, esquizofrenia, transtorno obsessivocompulsivo, síndrome de Tourette, depressão e transtornos do humor, bem como distúrbios autoimunes e neurodegenerativos. Evidências emergentes também apontam para a importância do eixo intestino-cerebral e do microbioma de um indivíduo em relação à sua saúde e bem-estar somático e mental. Conclusões: Existem interconexões multidirecionais entre múltiplos sistemas biológicos em nossos cérebros e corpos que são mediados em parte pelo sistema imunológico. No momento, no entanto, a "promessa" desse campo continua sendo maior do que os "resultados finais". O tempo dirá se novas intervenções serão desenvolvidas que farão uma diferença positiva no cuidado de nossos pacientes. Também é possível que surjam biomarcadores válidos que orientarão uma abordagem mais personalizada ao tratamento.

Descritores: Sistema imunitário; Imunologia; Transtornos do neurodesenvolvimento; Microglia; Imunidade materno-adquirida; Neuroimunomodulação; Citocinas; Transtorno autístico; Transtorno do espectro autista; Esquizofrenia; Transtorno obsessivo-compulsivo; Síndrome de Tourette; Depressão; Transtornos do humor; Estresse psicológico.

\footnotetext{
1. Child Study Center, Yale University, New Haven, CT, USA. ORCID: Leckman JF - https://orcid.org/0000-0002-3902-4478. Email: james.leckman@ yale.edu.

2. Department of Psychiatry, University of São Paulo, São Paulo, Brazil. ORCID: Alvarenga PG - https://orcid.org/0000-0002-2131-8718; Ravagnani B - https://orcid.org/0000-0002-6077-9461. Emails: pedrodealvarenga@gmail.com, ravagnani.beatriz@gmail.com.

3. Yale School of Medicine, New Haven, CT, USA. Email: isaac.johnson@yale.edu.

Correspondence: James F. Leckman. Email: james.leckman@yale.edu.
} 


\section{INTRODUCTION}

Tn the not too distant past, the 'immune system' was viewed as a complex set of cellular and molecular processes that protect us against pathogens from viruses and bacteria to parasitic worms. It is now clear that the cellular and molecular processes that make up our 'immune system' are also crucial to normal brain development and the formation of neural circuits. It is also becoming increasingly evident that the immune system plays a key role in the pathobiology of a number of neuropsychiatric and neurodegenerative disorders. This review summarizes the currently available literature across multiple domains and highlights how a deeper understanding of neuroimmunology is transforming the field of neuropsychiatry. A hallmark of this emerging area of science is the vast complexity of the nervous and immune systems and how interconnected they are with one another.

\section{METHODS}

This review article summarizes information assembled from a number of publications and systematic reviews of the scientific literature and is focused on the interface between the immune and nervous systems from early embryonic development through adolescence and adulthood. This includes the importance of the on-going "cross-talk" between the two systems, as it relates to the emergence of neurodevelopmental and neuropsychiatric disorders. Examples of summarized literature include, a special issue of Science magazine on 'Brain Development' published in October 2018'. Other examples include the articles published in a recent special issue of Biological Psychiatry on 'Prenatal programming of neuropsychiatric disorders across the lifespan' that was published earlier this year in January $2019^{2}$. The content of earlier special issues of Science, Biological Psychiatry and Brain Research were also reviewed ${ }^{3-6}$. Additional review articles were accessed in PubMed by linking terms related to immunobiology with specific neuropsychiatric and neurodevelopmental disorders including Autism Spectrum Disorder (ASD), schizophrenia, obsessive-compulsive disorder (OCD), Tourette syndrome (TS), attention deficit hyperactivity disorder (ADHD), depression and mood disorders among others. In addition, PubMed searches were performed using key words and phrases that included: microglia, innate immune system, adaptive immune system, cytokines, maternal immune activation (MIA), neuro-immune network hypothesis, microbiota, microbiome, and the 'gut-brain axis'.

\section{RESULTS}

The emerging knowledge concerning the role that the immune system plays in specific neurodevelopmental and neuropsychiatric disorders, and several related topics are highlighted. They include: (i) microglia and the role of the immune system in early brain development; (ii) genetic determinants of immune function; (iii) stress, neuroinflammation, maternal immune activation (MIA) and the neuro-immune network hypothesis; and (iv) the microbiome and 'gut-brain axis.'

\section{Microglia and the role of the immune system in normal brain development and neuropsychiatric disorders}

Recent advances in our understanding of normal brain development highlight the important role played by the microglia ${ }^{7-11}$. Microglia are the resident macrophage population of the central nervous system (CNS). They originate from the yolk sac that colonizes the embryonic human CNS from as early as the 4th week of gestation and they constitute $5-15 \%$ of the cells in the $\mathrm{CNS}^{12}$. Microglia are not only among the first immune sentinels of infection, but they are also involved in early brain development. Initially, they were recognized as critical players in sculpting neuronal connectivity in the developing brain through synaptic pruning ${ }^{13-15}$. In addition to sculpting synaptic connectivity, emerging data show that microglia enter the embryonic brain before the differentiation of other CNS cell types and are critical regulators of early brain development, including regulating the number and maturation of neural precursors and other resident CNS cell types ${ }^{12,13}$. Based on preliminary studies in adult mice, it appears that migrating microglia develop region-specific and sex-specific features, including the suggestion that female microglia are neuroprotective while male microglia are pro-inflammatory in character ${ }^{14}$. Microglia have also been shown to relay crucial information from the periphery to the CNS, including signals derived from the microbiota ${ }^{16}$. These findings underscore the importance of studying neurodevelopment as part of a broader framework that considers nervous system interactions with microglia and the immune system in a 'whole-body' context.

Evidence from human studies suggests that microglia are dysfunctional in at least a subset of individuals with neuropsychiatric disorders, as well as in neurodegenerative disorders such as Alzheimer's disease and chronic pain ${ }^{17}$. The range of neuropsychiatric disorders associated with at least some evidence of microglia dysfunction is broad and the list includes: Autism Spectrum Disorder (ASD), schizophrenia, bipolar disorder, major depression, OCD, and Tourette syndrome (TS) ${ }^{17-21}$. For example, postmortem studies of brain tissue from a small number of individuals with ASD have documented altered numbers of microglia in the dorsolateral prefrontal cortex ${ }^{22-24}$. Whole transcriptional analyses of postmortem brain tissue have also found that some individuals with ASD have altered expression of microglia-specific genes ${ }^{25,26}$. Similar findings in a subset of subjects with ASD have been documented using 
positron emission tomography (PET). Brain regions with increased binding of a radiotracer to microglia included the cerebellum, midbrain, pons, fusiform gyri, and the anterior cingulate and orbitofrontal cortices ${ }^{27}$. Likewise, studies of postmortem brain tissue from individuals with schizophrenia also support the role of the immune system, including the activation of microglia. For example, a recent meta-analysis identified 41 studies reporting on 783 patients and 762 controls. They found convincing evidence of a significant increase in the density of microglia in the brains of schizophrenic patients compared with controls. This increase was most consistently observed in the temporal corte $^{28}$. Elevated levels of microglia immunoreactivity have also been reported in the cortex of depressed individuals, as well as in brain tissue from individuals who committed suicide ${ }^{29,30}$. More recently, Setiawan et al. ${ }^{31}$ reported evidence for microglia activation during major depressive episodes using positron emission tomography. These changes were significant in the prefrontal cortex, anterior cingulate cortex and insula. Greater microglia activation in the insula was correlated with the level of depressive symptom severity ${ }^{31}$.

In the case of TS and OCD, preliminary findings from studies of postmortem brain tissue and brain imaging studies also indicate that immune activation is present in some individuals with TS and childhood-onset $\mathrm{OCD}^{21,32}$. More specifically, in the postmortem study, transcriptome data from the caudate nucleus and putamen from 9 TS and 9 matched control subjects identified 309 down-regulated and 822 up-regulated genes, in the patients with $\mathrm{TS}^{21}$. Using Weighted Gene Co-expression Network Analysis, 17 differentially expressed pathways or groups of genes were identified ${ }^{33}$. The power of this strategy is that it permits investigators to examine how genes and their products function in concert, rather than individually. The top-scoring down-regulated module was enriched for interneuron transcripts. However, the top-scoring up-regulated module was enriched with immune-related genes, associated with both the innate and adaptive immune systems. The pathway analyses pointed to the likely role of the microglia ${ }^{20,21}$. A PET brain imaging study that used a radioligand associated with activation of the innate immune system, found evidence of microglia mediated neuroinflammation in the bilateral caudate nuclei in 12 children with TS. In this same PET study, neuroinflammation was also seen in the bilateral lentiform nucleus, as well as in the bilateral caudate nuclei, in 15 children diagnosed with PANDAS (Pediatric Autoimmune Neuropsychiatric Disorders Associated with Streptococcal Infections). Future studies are needed to confirm these findings ${ }^{32}$.

PANDAS was first described by Susan Swedo and her team at the National Institute of Mental Health in $1998^{34}$. The diagnostic criteria for PANDAS includes an abrupt "overnight" onset of OCD and other neuropsychiatric symptoms including tics, anxiety, emotional lability, enuresis, and attentional problems. The onset of PANDAS is in childhood. In some cases, these symptoms manifest a relapsing-remitting, episodic symptom course in the aftermath of an infection with group A beta-hemolytic streptococcal infections (GAS), as seen with Sydenham's chorea. PANDAS has been proposed to result from antibodies raised against GAS cross-reacting with brain antigens, based in part on molecular mimicry. However, the targets of these antibodies are not entirely clear and may be heterogeneous ${ }^{35,36}$.

Currently, PANDAS remains a controversial topic ${ }^{37}$. Despite continued debates about the role of GAS infections in the etiopathogenesis of PANDAS, experts on both sides of the controversy agree that a subgroup of children with OCD have an unusually abrupt onset of symptoms, accompanied by a variety of comparably severe and acute neuropsychiatric symptoms. The acuity of symptom onset is the hallmark feature of their clinical presentation and is the basis for the name proposed for an expanded clinical entity: Pediatric Acute-onset Neuropsychiatric Syndrome (PANS). PANS does not require specific association with GAS and can be related to other infectious factors ${ }^{38}$. Modifying the PANDAS criteria to eliminate etiologic factors and to clarify the time-course of the initial clinical presentation is a step in the right direction, in our opinion.

However, in one recent study, serum was collected from children with well-characterized PANDAS $(n=5)$ who responded well to a course of intravenous gamma globulin (IVIG) and matched controls. The serum was then infused into the striatum of mice ${ }^{39}$. Antibodies from children with PANDAS bound to $\sim 80 \%$ of cholinergic interneurons, significantly higher than the $<50 \%$ binding seen with matched healthy controls. Remarkably, after treatment with IVIG, symptom improvement resolved in parallel with a reversal of the elevated binding of antibodies to cholinergic interneurons ${ }^{40}$. Individuals with TS have fewer cholinergic interneurons in their striatum, based on the examination of postmortem brain tissue ${ }^{41}$. Future clarification of the functional consequences of this specific binding may provide new opportunities to identify and successfully intervene in children with PANDAS and PANS.

\section{Genetic risk}

The etiology of neurodevelopmental and neuropsychiatric disorders is complex and involves an individual's genetic background as well as exposure to a range of risk factors from conception onwards. For example, the high rates of heritability for ASD clearly indicate that genes play an important role in its etiology ${ }^{42}$. Over the past decade, a multitude of risk genes have been identified $^{43}$. Their risk effects are highly variable, but many different variants converge on common biological 
pathways, including the immune system ${ }^{44}$. Intriguingly, some of these risk genes are located on Chromosome 6, which is densely packed with genes that code for immune molecules, particularly molecules within the major histocompatibility complex (HLA) ${ }^{45}$. These HLA genes code for cell-surface proteins that are responsible for the regulation of the immune system.

Studies of human brain tissue from individuals on the autism spectrum also implicate the involvement of the immune system. For example, transcriptomes from three cortical brain regions, BA10, BA14, and BA 44, from 104 subjects with ASD were sequenced. The pathway analyses from this large-scale RNA sequencing effort utilized regionmatched ASD and control brains, and strongly indicated that microglial genes are significantly dysregulated in these cortical regions. This analysis also highlights the interplay between innate immunity and neuronal activity in the etiology of $\mathrm{ASD}^{25}$. Similarly, a genome-wide methylation study of the prefrontal cortex found a significant enrichment for genomic regions responsible for immune function, specifically hypo-methylated $\mathrm{CpGs}^{46,47}$. More recently, a weighted gene correlation network analysis detected 3 comethylation modules, which were significantly correlated with the ASD phenotype. These modules were enriched for genomic regions underlying neuronal, GABAergic, and immune system genes ${ }^{48}$.

The etiology of schizophrenia is also complex. Like ASD, there is a substantial body of data indicating that genetic factors, immune dysregulation and neuroinflammation are all involved in at least a subset of cases. Whole genome analyses have identified 108 conservatively defined loci that meet genome-wide significance ${ }^{49,50}$. Many of these genes are highly expressed in the brain, as well as in immune function, including the HLA region on chromosome $6^{51}$. A more recent study completed a genome-wide expression analysis in peripheral blood mononuclear cells from U.S. veterans with schizophrenia $(\mathrm{n}=52)$ and controls. A total of 167 differentially expressed genes were identified. Many of these genes were enriched primarily for pathways related to inflammatory mechanisms and immune cell trafficking ${ }^{52}$.

TS, OCD, and ADHD are also highly heritable conditions $^{53-58}$. Despite evidence for a substantial genetic contribution to disease risk, the identification and replication of genetic variants associated with these related conditions has been challenging. In the case of TS, the use of rare variant approaches has identified two genes of major effect. One is involved in synaptic development ${ }^{59}$ and another is associated with histaminergic transmission ${ }^{60}$. Overall, GWAS studies for TS, OCD and ADHD have identified a large number of risk genes of minor effect, some of which impact immune function ${ }^{61}$. For example, a GWAS study (1,285 TS subjects and 4,964 controls) implicated several pathways related to specific astrocytic, oligodendrocytic and microglial activity, as well as to synaptic function ${ }^{62}$. More recently, Tylee et al. ${ }^{50}$ re-examined the available
GWAS data from individuals with TS, OCD, and ADHD and found significant genetic correlations between psychiatric and immune-related phenotypes based on genome-wide association data. These findings are also consistent with the findings of two large scale, populationbased, epidemiological studies from Denmark and Sweden, which have documented that some individuals with OCD, $\mathrm{TS}$, and ADHD have an increased risk for developing an autoimmune disorder ${ }^{63-65}$. Conversely, Hounie et al. ${ }^{66}$ some years earlier documented in a case-control study conducted in Brazil that a familial relationship exists between rheumatic fever (RF) and OCD-related disorders when considered in aggregate $(\mathrm{OCD}$, subclinical OCD, $\mathrm{TS}$, chronic tic disorders, transient tic disorders). If an individual has a family history of RF, then he/she is at greater risk of developing OCD and/or related disorders. The rate of these OCD-related conditions (ORC) among the first-degree relatives of rheumatic fever probands was significantly higher than the rate among the first-degree relatives of control subjects. The rate of these ORCs was highest among the first-degree relatives of rheumatic fever probands who also had an ORC. However, the rate of ORCs was also higher among the first-degree relatives of RF probands without an ORC, although the difference was not statistically significant ${ }^{66}$.

\section{Stress, Neuroinflammation, Maternal Immune Activation, and the Neuro-immune Network Hypothesis}

'Stress' includes multiple modalities that can be biological, social and/or psychological in character. Threatening physical or psychological stressors are sensed at many levels in the human body and the CNS. This information is then passed on to the hypothalamus after being processed by various limbic regions before it is communicated to the adrenal gland. This signaling pathway is evolutionarily conserved in mammalian species, and it is commonly referred to as the hypothalamic-pituitary-adrenal (HPA) axis. Activation of the HPA axis in response to stressful stimuli can, in turn, induce a variety of hormonal, immunological, cardiovascular and autonomic responses that impact multiple organ systems over the course of development ${ }^{15}$. Early-life adversity, sometimes referred to as 'toxic stress,' can amplify the crosstalk between the immune system and the neural circuits that encompass threat-related, reward-related, and executive control-related processes ${ }^{67}$. This crosstalk in the neuro-immune network can then, in turn, contribute to a number of somatic, neurodevelopmental and neuropsychiatric disorders ${ }^{4,68,69}$. Remarkably, in the case of mothers, stressful events occurring during a child's gestation can set the stage for adverse outcomes much later in the child's life $e^{4,15,67,68,70,71}$. In the case of fathers, it also appears that stressful events occurring pre-conception can have an adverse long-term $\operatorname{impact}^{72}$. 
Epidemiological studies provide compelling evidence that perturbations in the prenatal and perinatal environments are associated with an increased risk of offspring developing neuropsychiatric disorders including $\mathrm{ASD}^{71,73-80}$, schizophrenia ${ }^{68,71,81-85}$, mood and affective disorders ${ }^{71,86-92}, \mathrm{OCD}^{93-95}, \mathrm{ADHD}^{96-98}$, and $\mathrm{TS}^{99-102}$. These studies have identified a number of factors that can contribute to an individual's risk of developing one or more of these disorders. They range from maternal infections, especially those associated with high fevers and a need for hospitalization $^{82}$, inadequate nutrition ${ }^{86,87}$ as well as stressful life events occurring prenatally or during the first months of a child's life ${ }^{88}$.

In ASD, the link between pre-term birth and the emergence of ASD traits is well established ${ }^{103}$. There is also evidence supporting a link between immune system dysfunction and both pre-maturity and $\mathrm{ASD}^{104}$. Dozens of other environmental risk factors have been identified that impact the developing brain. The strongest evidence to date concerns Maternal Immune Activation (MIA). As noted above, multiple epidemiological studies implicate maternal infection and heightened levels of maternal stress during gestation and the perinatal period as risk factors for $\mathrm{ASD}^{68,70,105-110}$. In a recent meta-analysis of 15 studies involving more than 40,000 cases of ASD, maternal infection during pregnancy was associated with an increased risk of ASD in the offspring. This was especially true for those requiring hospitalization. This risk was likely modulated by the individual's genetic background, the type of infectious agent, the time of the exposure, and the site of infection $^{79}$. All of this points to the importance of the neuroimmune interface early in brain and somatic development ${ }^{111}$. There is also a growing body of data linking ASD with autoimmunity and allergies ${ }^{12-114}$. Wu et al. ${ }^{113}$ conducted a meta-analysis of 11 studies that found that a family history of any autoimmune disorder was associated with a $28 \%$ higher risk of ASD in children. Several autoimmune disorders significantly contributed to this finding including hypothyroidism $(\mathrm{OR}=1.64)$, type 1 diabetes $(\mathrm{OR}=1.49)$, rheumatoid arthritis $(\mathrm{OR}=1.51)$, and psoriasis $(\mathrm{OR}=1.59)$. Another more recent study investigated maternal immune conditions during gestation, as well as the lifetime history of these conditions in family members. Logistic regression analyses included 663 children on the autism spectrum, 984 children with a developmental disability, and 915 controls. A maternal history of eczema/psoriasis and asthma was associated with a $20 \%-40 \%$ increased odds of both ASD and a developmental disability. In addition, children on the spectrum were also more likely to have had a history of psoriasis/eczema or allergies. No association was observed for paternal history of these immune conditions ${ }^{12}$. Interestingly, another recent study of a nationally representative sample of U.S. children $(n=$ 199,520) found a significant association of a broad range of allergies (food, respiratory, and skin) with $\mathrm{ASD}^{114}$. In the immune-mediated subtype of ASD, it is possible that this association may impact the composition of an individual's microbiome which may affect the functioning of the 'gutbrain axis' ${ }^{\prime 15}$.

Finally, there have also been several studies examining the peripheral immune markers associated with ASD. For better or worse, the scientific literature is inconsistent in that no single marker has been found to be abnormal consistently across all of the studies ${ }^{116-121}$. One of the most compelling studies was performed at University of California, Davis and involved an examination of neonatal blood spots from 214 children with ASD (141 severe, $73 \mathrm{mild} /$ moderate), 27 children with developmental delays; and 62 typically developing children. Levels of 17 cytokines and chemokines were compared across groups and in relation to developmental and behavioral domains. The levels of Interleukin (IL)-1 $\beta$ \& IL-4 in the neonatal blood specimens were independently associated with ASD. Elevated IL-4 was associated with the severe ASD phenotype and IL-1 $\beta$ was associated with the mild/moderate ASD phenotype. IL-4 was also negatively associated with nonverbal cognitive ability ${ }^{122}$. Fewer studies have examined the CNS directly, through the cerebrospinal fluid (CSF) or brain tissues. Vargas et al. ${ }^{23}$ found increased levels of pro-inflammatory and immunomodulatory cytokines, differentially expressed across the cortical regions in postmortem samples from individuals with ASD $(n=11)$. In contrast, Pardo et al. ${ }^{121}$ were able to track immune markers in the CSF longitudinally. They found striking differences in the expression of selected cytokines, immune-related growth factors, and chemokines that varied over time, when comparing ASD and neurotypical samples.

The environmental risk factors associated with an increased risk of developing schizophrenia include: advanced paternal age ( $>50$ y.o. at birth), prenatal maternal malnutrition, prenatal infections (influenza), obstetrical complications and a low birth weight ${ }^{85,123-126}$. There is also a growing body of data linking schizophrenia with autoimmunity and allergies ${ }^{127-129}$.

Clinical and epidemiological studies have also explored a number of potential pre- and perinatal risk factors associated with the risk of developing OCD, TS and ADHD. These include inadequate or excessive maternal weight gain, maternal tobacco, alcohol and cannabis use, hyperemesis gravidarum, prolonged labor, preterm birth, and jaundice, as well as high levels of maternal depression and anxiety $93,95-99,101,102,130$. The findings vary from study to study and more work needs to be done before any firm conclusions can be reached concerning the possible role MIA may play in the pathogenesis of these disorders. In addition to these genetic and epidemiological findings, there is an emerging body of preliminary data that is focused on inflammatory markers (cytokine and immunoglobulin levels), immune cell populations, and gene expression profiling of peripheral lymphocytes. These data indicate 
some degree of hyperactivity of both the innate and the adaptive immune systems in TS, childhood-onset OCD and $\mathrm{ADHD}^{131-135}$.

\section{The microbiome, perinatal nutrition and the 'gut-brain axis'}

Aberrations in the microbiome after Maternal Immune Activation (MIA) can lead to altered development of peripheral immunity, both of which can alter brain development. Over the past two decades, the microbiome has emerged as an area of great scientific interest. Human microbiota includes bacteria, fungi, archaea and viruses ${ }^{136}$. As a species, our bodies contain many more non-human cells than human cells ${ }^{137}$. It is now clear from both animal models and human studies that the composition of an individual's microbiota has an impact on their health and wellbeing ${ }^{138}$. For example, developmentally, preclinical findings in animal models suggest that the gut microbiome plays a pivotal role in regulating microglial maturation and function and that this bidirectional crosstalk between the gut and the brain may influence disease pathogenesis ${ }^{139}$. Indeed, animal models have provided the most compelling evidence that gut bacteria and their metabolites play a role in CNS homeostasis and that they can directly affect behavior. Maternal and infant diet, stress, mode of delivery, e.g., vaginal vs. C-section, maternal infections, and antibiotic exposures all shape early microbial colonization patterns ${ }^{140,141}$. How enduring these patterns are, and what, if any, long-term phenotypic impact they have on disease and neurodevelopment is currently being explored. Human studies have been primarily correlative in nature, so caution is warranted and must be applied before concluding that the composition of an individual's microbiota has a direct causal role in the pathogenesis of psychiatric disease.

Research on the microbiome of individuals with ASD is the most advanced ${ }^{142,143}$ and studies are now underway that are exploring the impact of microbiome transfer therapy ${ }^{144}$. Efforts to understand the role of the microbiome are also underway with regard to a number of other disorders including schizophrenia and bipolar disorder ${ }^{145-150}$, TS, OCD, and related disorders including PANS and PANDAS ${ }^{151-153}$, major depression and mood disorders $^{154,155}$, alcohol use and eating disorders ${ }^{156}$, as well as neurodegenerative disorders ${ }^{157}$.

Another key mechanism concerns the "gut-brain axis." This axis involves the neural and molecular signaling that takes place between the gastrointestinal (GI) tract and the CNS ${ }^{158-161}$. Not surprisingly, maternal stress, the HPA axis, the sympathetic and parasympathetic arms of the autonomic nervous system, as well as the individual's dietary intake and the composition of their microbiome all play an important role. The microbiota in the GI tract can influence CNS functions due to its ability to synthesize a wide range of molecules including neurotransmitters and their precursors, e.g., acetylcholine, gamma-aminobutyric acid (GABA), serotonin, catecholamines, melatonin, and histamine ${ }^{158}$. These interconnected systems are established shortly after birth and are influenced by a number of factors including: maternal psychosocial stress, infections, antimicrobial treatments, mode of delivery and obstetrical complications, as well as maternal and child dietary intake including breast feeding ${ }^{130,162}$. Remarkably, there is now evidence from animal models and human studies that the 'microbiota-gut-brain axis' can influence gene expression and brain microstructure, as well as host stress-induced behavior, social interactions and learning and memory task performance ${ }^{162-166}$.

Another truly amazing finding is that bacteria appear to be present in both human $(\mathrm{n}=34)$ and mouse brains under noninfectious or nontraumatic conditions. These findings were presented as a poster at the Society for Neuroscience annual meeting in San Diego in November of 2018. The density of the bacteria varied by brain region, with abundant bacteria in the substantia nigra, hippocampus and prefrontal cortex. The observed bacteria were present in intracellular locations within astrocytes located near the blood brain barrier. They were also abundant adjacent to the blood brain barrier and within myelinated axons. RNA sequencing revealed that most of the bacteria were from three phyla common to the gut: Firmicutes, Proteobacteria, and Bacteroidetes ${ }^{167}$. If replicated, it will be important to examine postmortem tissue from individuals with neurodevelopmental and neuropsychiatric disorders to determine if gut microbiota are present and, if so, how they vary from disorder to disorder.

\section{DISCUSSION}

The combination of an individual's genetic background, autoimmune status and a range of other factors including MIA and an individual's 'microbiota-gut-brain axis' set the stage for the emergence of neurodevelopmental, neuropsychiatric, and neurodegenerative disorders. In some instances, "second hits" during childhood and adolescence, including stress and substance use, may be key factors as well. In this review we have briefly summarized the published data concerning the role of the immune system in the pathobiology of several neurodevelopmental and neuropsychiatric disorders including ASD and schizophrenia as well as OCD, ADHD and tic disorders. At present, the available data highlight the findings of epidemiological, genetic, and post-mortem studies, as well as, cross-sectional and longitudinal studies of immune activation in the periphery. We have also briefly summarized the results of studies that seek to characterize the microbiota associated with these disorders. We have reviewed the current state-of-the-art with regard to the therapeutic potential for immunomodulatory interventions for each of these conditions. 
In closing, we highlight the value of animal model systems particularly with regard to embryonic development. Embryonic development captures a particularly complex period, in which genetic and environmental factors can interact to contribute to risk. In addition to clinical and epidemiological studies, this field of research has been driven by the use of animal model systems ${ }^{9,11,140,168-170}$. For example, animal research has documented that inflammatory perturbations in the developing brain can divert microglia from their normal physiological role to a potentially more pathological role, both in the short-and long-term ${ }^{11,171,172}$. Maternal inflammation generally can increase microglial density and/or activation in the offspring brain ${ }^{173}$. These changes begin embryonically, as demonstrated by increased microglial density and reactivity a few days after the midor late-gestation administration of immuno-stimulatory compounds such as lipopolysaccharide (LPS), which mimic infections by gram-negative bacteria ${ }^{174,175}$. LPS stimulates the production of many endogenous proinflammatory cytokines including interleukin-1b(IL-1b), IL-6, and tumor necrosis factor alpha (TNF-alpha), which, along with other factors, recruit, activate, and stimulate the production of immune cells ${ }^{174-176}$. Additionally, microglial and cytokine changes in the developing brain may directly influence synaptic plasticity as well as increase the reactivity of an animal's immune system to subsequent immune challenges in adulthood ${ }^{7,177,178}$.

It is also important to highlight the role of the placenta, as it plays a very significant role in prenatal

\section{REFERENCES}

1. Hines PJ. Mind-boggling brain development. Science. 2018;362(6411):170-1. doi: 10.1126/science.aav5687.

2. Epperson CN, Bale TL. Deciphering the Brain Before Birth. Biol Psychiatry. 2019;85(2):90. doi: 10.1016/j. biopsych.2018.11.005.

3. Leckman JF, Vaccarino FM. Editorial commentary: "What does immunology have to do with brain development and neuropsychiatric disorders?". Brain Res. 2015;1617:1-6. doi: 10.1016/j.brainres.2014.09.052.

4. Nusslock R, Miller GE. Early-life adversity and physical and emotional health across the lifespan: a neuroimmune network hypothesis. Biol Psychiatry. 2016;80(1):23-32. doi: 10.1016/j. biopsych.2015.05.017.

5. Mueller KL, Hines PJ, Travis J. Neuroimmunology. Science. 2016;353(6301):760-1. doi: 10.1126/science.353.6301.760.

6. McAllister AK. Immune contributions to cause and effect in autism spectrum disorder. Biol Psychiatry. 2017;81(5):380-2. doi: 10.1016/j.biopsych.2016.12.024.

7. Allen NJ, Lyons DA. Glia as architects of central nervous system formation and function. Science. 2018;362(6411):1815. doi: $10.1126 /$ science.aat 0473 .

8. Cowan M, Petri WA, Jr. Microglia: Immune regulators of neurodevelopment. Frontiers Immunol. 2018;9:2576. doi: 10.3389/fimmu.2018.02576.

9. Li Q, Barres BA. Microglia and macrophages in brain homeostasis and disease. Nat Rev Immunol. 2018;18(4):225- immune-neurodevelopmental interactions. The placenta is highly immunologically specialized, and it can serve both as a conduit for and regulator of immune factor traffic at the maternal-fetal interface ${ }^{177}$. Animal models have also documented the transgenerational inheritance of behavioral and metabolic effects of paternal exposure to traumatic stress in early postnatal life ${ }^{179}$. In sum, differences certainly exist between rodents and humans that limit the value of animal model systems, with regard to a number of relevant variables including developmental timing in utero, placental morphology, hormone production, and immunoregulatory protein expression. However, the ability of animal model systems to posit causal mechanisms using experimental designs is an obvious strength ${ }^{170,177,180}$.

Some of the unanswered questions that are fundamental to this area of research include how and why the onset of specific neuropsychiatric disorders is often separated by years or decades from early developmental disruptions associated with MIA. Despite limitations, animal models provide critical data supporting prenatal inflammatory programming of the brain and will be fundamentally involved as immunome-level analyses and other innovative methods are developed. Hopefully, advances in developmental neuroscience that link prenatal events with subsequent brain-development events will provide a foundation on which the pathophysiology of various psychiatric disorders can be better understood and more adequately treated ${ }^{144,148,181-184}$.

\section{2. doi: 10.1038/nri.2017.125.}

10. Liberman AC, Trias E, da Silva Chagas L, Trindade P, Dos Santos Pereira M, Refojo D, Hedin-Pereira C, Serfaty CA. Neuroimmune and inflammatory signals in complex disorders of the central nervous system. Neuroimmunomodulation. 2018;25(5-6):246-270. doi: 10.1159/000494761.

11. Thion MS, Ginhoux F, Garel S. Microglia and early brain development: an intimate journey. Science. 2018;362(6411):185-9. doi: 10.1126/science.aat0474.

12. Schafer DP, Lehrman EK, Kautzman AG, Koyama R, Mardinly AR, Yamasaki R, et al. Microglia sculpt postnatal neural circuits in an activity and complement-dependent manner. Neuron. 2012;74(4):691-705. doi: 10.1016/j. neuron.2012.03.026

13. Frost JL, Schafer DP. Microglia: architects of the developing nervous system. Trends Cell Biol. 2016;26(8):587-97. doi: 10.1016/j.tcb.2016.02.006.

14. Villa A, Gelosa P, Castiglioni L, Cimino M, Rizzi N, Pepe G, et al. Sex-specific features of microglia from adult mice. Cell Rep. 2018;23(12):3501-11. doi: 10.1016/j.celrep.2018.05.048.

15. Goldstein JM. Impact of Prenatal stress on offspring psychopathology and comorbidity with general medicine later in life. Biol Psychiatry. 2019;85(2):94-6. doi: 10.1016/j. biopsych.2018.03.002.

16. Erny D, Hrabe de Angelis AL, Jaitin D, Wieghofer P, Staszewski O, David E, et al. Host microbiota constantly 
control maturation and function of microglia in the CNS. Nat Neurosci. 2015;18(7):965-77. doi: 10.1038/nn.4030.

17. Salter MW, Stevens B. Microglia emerge as central players in brain disease. Nat Med. 2017;23(9):1018-27. doi: 10.1038/ nm.4397.

18. Attwells S, Setiawan E, Wilson AA, Rusjan PM, Mizrahi R, Miler L, et al. Inflammation in the neurocircuitry of obsessivecompulsive disorder. JAMA Psychiatry. 2017;74(8):833-40. doi: 10.1001/jamapsychiatry.2017.1567.

19. Frick LR, Williams K, Pittenger C. Microglial dysregulation in psychiatric disease. Clin Dev Immunol. 2013;2013:608654. doi: 10.1155/2013/608654.

20. Frick L, Pittenger C. Microglial dysregulation in OCD, Tourette syndrome, and PANDAS. J Immunol Res. 2016;2016:8606057. doi: 10.1155/2016/8606057.

21. Lennington JB, Coppola G, Kataoka-Sasaki Y, Fernandez TV, Palejev D, Li Y, et al. Transcriptome analysis of the human striatum in Tourette syndrome. Biol Psychiatry. 2016;79(5):372-82. doi: 10.1016/j.biopsych.2014.07.018.

22. Morgan JT, Chana G, Pardo CA, Achim C, Semendeferi $\mathrm{K}$, Buckwalter J, et al. Microglial activation and increased microglial density observed in the dorsolateral prefrontal cortex in autism. Biol Psychiatry. 2010;68(4):368-76. doi: 10.1016/j.biopsych.2010.05.024.

23. Vargas DL, Nascimbene C, Krishnan C, Zimmerman AW, Pardo CA. Neuroglial activation and neuroinflammation in the brain of patients with autism. Ann Neurol. 2005;57(1):6781. doi: 10.1002/ana.20315.

24. Tetreault NA, Hakeem AY, Jiang S, Williams BA, Allman E, Wold BJ, et al. Microglia in the cerebral cortex in autism. J Autism Dev Disord. 2012;42(12):2569-84. doi: 10.1007/ s10803-012-1513-0.

25. Gupta S, Ellis SE, Ashar FN, Moes A, Bader JS, Zhan J, et al. Transcriptome analysis reveals dysregulation of innate immune response genes and neuronal activity-dependent genes in autism. Nat Commun. 2014;5:5748. doi: 10.1038/ ncomms6748.

26. Voineagu I, Wang X, Johnston P, Lowe JK, Tian Y, Horvath S, et al. Transcriptomic analysis of autistic brain reveals convergent molecular pathology. Nature. 2011;474(7351):380-4. doi: 10.1038/nature10110.

27. Suzuki K, Sugihara G, Ouchi Y, Nakamura K, Futatsubashi $\mathrm{M}$, Takebayashi $\mathrm{K}$, et al. Microglial activation in young adults with autism spectrum disorder. JAMA Psychiatry. 2013;70(1):49-58. doi: 10.1001/jamapsychiatry.2013.272.

28. van Kesteren CF, Gremmels H, de Witte LD, Hol EM, Van Gool AR, Falkai PG, et al. Immune involvement in the pathogenesis of schizophrenia: a meta-analysis on postmortem brain studies. Transl Psychiatry. 2017;7(3):e1075. doi: 10.1038/tp.2017.4.

29. Steiner J, Bielau H, Brisch R, Danos P, Ullrich O, Mawrin C, et al. Immunological aspects in the neurobiology of suicide: elevated microglial density in schizophrenia and depression is associated with suicide. J Psychiatr Res. 2008;42(2):151-7. doi: 0.1016/j.jpsychires.2006.10.013.

30. Steiner J, Walter M, Gos T, Guillemin GJ, Bernstein HG, Sarnyai Z, et al. Severe depression is associated with increased microglial quinolinic acid in subregions of the anterior cingulate gyrus: evidence for an immune-modulated glutamatergic neurotransmission? J Neuroinflammation. 2011;8:94. doi: 10.1186/1742-2094-8-94.

31. Setiawan E, Wilson AA, Mizrahi R, Rusjan PM, Miler L, Rajkowska G, et al. Role of translocator protein density, a marker of neuroinflammation, in the brain during major depressive episodes. JAMA Psychiatry. 2015;72(3):268-75. doi: 10.1001/jamapsychiatry.2014.2427.

32. Kumar A, Williams MT, Chugani HT. Evaluation of basal ganglia and thalamic inflammation in children with pediatric autoimmune neuropsychiatric disorders associated with streptococcal infection and tourette syndrome: a positron emission tomographic (PET) study using 11C-[R]-PK11195. J Child Neurol. 2015;30(6):749-56. doi: $10.1177 / 0883073814543303$.

33. Langfelder P, Horvath S. WGCNA: an R package for weighted correlation network analysis. BMC Bioinformatics. 2008;9:559. doi: 10.1186/1471-2105-9-559.

34. Swedo SE, Leonard HL, Garvey M, Mittleman B, Allen AJ, Perlmutter S, et al. Pediatric autoimmune neuropsychiatric disorders associated with streptococcal infections: clinical description of the first 50 cases. Am J Psychiatry. 1998;155(2):264-71. doi: 10.1176/ajp.155.2.264.

35. Cunningham MW, Cox CJ. Autoimmunity against dopamine receptors in neuropsychiatric and movement disorders: a review of Sydenham chorea and beyond. Acta Physiol (Oxf). 2016;216(1):90-100. doi: 10.1111/apha.12614.

36. Hesselmark E, Bejerot S. Biomarkers for diagnosis of Pediatric Acute Neuropsychiatric Syndrome (PANS) - sensitivity and specificity of the Cunningham Panel. J Neuroimmunol. 2017;312:31-7. doi: 10.1016/j.jneuroim.2017.09.002.

37. Gamucci A, Uccella S, Sciarretta L, D’Apruzzo M, Calevo MG, Mancardi MM, et al. PANDAS and PANS: Clinical, Neuropsychological, and Biological Characterization of a Monocentric Series of Patients and Proposal for a Diagnostic Protocol. J Child Adolesc Psychopharmacol. 2019; 29(4):305-312. doi: 10.1089/cap.2018.0087.

38. Swedo SE, Leckman JF, Rose NR. From research subgroup to clinical syndrome: modifying the PANDAS criteria to describe PANS (Pediatric Acute-onset Neuropsychiatric Syndrome). Pediatr Therapeut. 2012;2(2):1000113. doi: 10.4172/2161-0665.1000113.

39. Williams KA, Swedo SE, Farmer CA, Grantz H, Grant PJ, D'Souza P, et al. Randomized, controlled trial of intravenous immunoglobulin for pediatric autoimmune neuropsychiatric disorders associated with streptococcal infections. J Am Acad Child Adolesc Psychiatry. 2016;55(10):860-7.e2. doi: 10.1016/j.jaac.2016.06.017.

40. Frick LR, Rapanelli M, Jindachomthong K, Grant P, Leckman JF, Swedo S, et al. Differential binding of antibodies in PANDAS patients to cholinergic interneurons in the striatum. Brain Behav Immun. 2018;69:304-11. doi: 10.1016/j. bbi.2017.12.004.

41. Kataoka Y, Kalanithi PS, Grantz H, Schwartz ML, Saper C, Leckman JF, et al. Decreased number of parvalbumin and cholinergic interneurons in the striatum of individuals with Tourette syndrome. J Comp Neurol. 2010;518(3):277-91. doi: 10.1002/cne.22206.

42. Tick B, Bolton P, Happe F, Rutter M, Rijsdijk F. Heritability of autism spectrum disorders: a meta-analysis of twin studies. J Child Psychol Psychiatry. 2016;57(5):585-95. doi: 10.1111/ jсpp.12499.

43. Yen RKC, Merico D, Bookman M, J LH, Thiruvahindrapuram $\mathrm{B}$, Patel RV, et al. Whole genome sequencing resource identifies 18 new candidate genes for autism spectrum disorder. Nat Neurosci. 2017;20(4):602-11. doi: 10.1038/ nn. 4524 .

44. Vorstman JAS, Parr JR, Moreno-De-Luca D, Anney RJL, Nurnberger JI Jr, Hallmayer JF. Autism genetics: opportunities and challenges for clinical translation. Nat 
Rev Genet. 2017;18(6):362-76. doi: 10.1038/nrg.2017.4.

45. Torres AR, Sweeten TL, Johnson RC, Odell D, Westover JB, Bray-Ward P, et al. Common Genetic Variants Found in HLA and KIR Immune Genes in Autism Spectrum Disorder. Front Neurosci. 2016;10:463. doi: 10.3389/fnins.2016.00463.

46. Nardone S, Sams DS, Reuveni E, Getselter D, Oron O, Karpuj M, et al. DNA methylation analysis of the autistic brain reveals multiple dysregulated biological pathways. Transl Psychiatry. 2014;4:e433. doi: 10.1038/tp.2014.70.

47. Nardone S, Elliott E. The Interaction between the immune system and epigenetics in the etiology of autism spectrum disorders. Front Neurosci. 2016;10:329. doi: 10.3389/ fnins.2016.00329.

48. Nardone S, Sams DS, Zito A, Reuveni E, Elliott E. Dysregulation of cortical neuron DNA methylation profile in autism spectrum disorder. Cereb Cortex. 2017;27(12):573954. doi: 10.1093/cercor/bhx250.

49. Schizophrenia Working Group of the Psychiatric Genomics Consortium. Biological insights from 108 schizophreniaassociated genetic loci. Nature. 2014;511(7510):421-7. doi: 10.1038/nature13595.

50. Tylee DS, Sun J, Hess JL, Tahir MA, Sharma E, Malik R, et al. Genetic correlations among psychiatric and immunerelated phenotypes based on genome-wide association data. Am J Med Genet B Neuropsychiatr Genet. 2018;177(7):64157. doi: 10.1002/ajmg.b.32652.

51. Shi J, Levinson DF, Duan J, Sanders AR, Zheng Y, Pe'er I, et al. Common variants on chromosome 6p22.1 are associated with schizophrenia. Nature. 2009;460(7256):753-7. doi: 10.1038/nature08192.

52. Fries GR, Dimitrov DH, Lee S, Braida N, Yantis J, Honaker C, et al. Genome-wide expression in veterans with schizophrenia further validates the immune hypothesis for schizophrenia. Schizophr Res. 2018;192:255-61. doi: 10.1016/j.schres.2017.06.016.

53. Fernandez TV, Leckman JF, Pittenger C. Genetic susceptibility in obsessive-compulsive disorder. Handb Clin Neurol. 2018;148:767-81. doi: 10.1016/B978-0-44464076-5.00049-1.

54. Fernandez TV, State MW, Pittenger C. Tourette disorder and other tic disorders. Hand Clin Neurol. 2018;147:343-54. doi: 10.1016/B978-0-444-63233-3.00023-3.

55. Brikell I, Kuja-Halkola R, Larsson H. Heritability of attention-deficit hyperactivity disorder in adults. Am J Med Genet B Neuropsychiatr Genet. 2015;168(6):406-13. doi: 10.1002/ajmg.b.32335.

56. Middeldorp CM, Hammerschlag AR, Ouwens KG, Groen-Blokhuis MM, Pourcain BS, Greven CU, et al. A Genome-wide association meta-analysis of attention-deficit/ Hyperactivity disorder symptoms in population-based pediatric cohorts. J Am Acad Child Adolesc Psychiatry. 2016;55(10):896-905.e6. doi: 10.1016/j.jaac.2016.05.025.

57. Bozorgmehr A, Ghadirivasfi M, Shahsavand Ananloo E. Obsessive-compulsive disorder, which genes? Which functions? Which pathways? An integrated holistic view regarding OCD and its complex genetic etiology. J Neurogenet. 2017;31(3):153-60. doi: 10.1080/01677063.2017.1336236.

58. Bidwell LC, Gray JC, Weafer J, Palmer AA, de Wit H, MacKillop J. Genetic influences on ADHD symptom dimensions: Examination of a priori candidates, gene-based tests, genome-wide variation, and SNP heritability. Am J Med Genet B Neuropsychiatr Genet. 2017;174(4):458-66. doi: 10.1002/ajmg.b.32535.

59. Abelson JF, Kwan KY, O'Roak BJ, Baek DY, Stillman
AA, Morgan TM, et al. Sequence variants in SLITRK1 are associated with Tourette's syndrome. Science. 2005;310(5746):317-20. doi: 10.1126/science.1116502.

60. Ercan-Sencicek AG, Stillman AA, Ghosh AK, Bilguvar K, O'Roak BJ, Mason CE, et al. L-histidine decarboxylase and Tourette's syndrome. N Engl J Med. 2010;362(20):1901-8. doi: 10.1056/NEJMoa0907006.

61. Khramtsova EA, Heldman R, Derks EM, Yu D, Davis LK, Stranger BE. Sex differences in the genetic architecture of obsessive-compulsive disorder. Am J Med Genet B Neuropsychiatr Genet. 2018. doi: 10.1002/ajmg.b.32687.

62. de Leeuw C, Goudriaan A, Smit AB, Yu D, Mathews CA, Scharf JM, et al. Involvement of astrocyte metabolic coupling in Tourette syndrome pathogenesis. Eur J Human Genet. 2015;23(11):1519-22. doi: 10.1038/ejhg.2015.22.

63. Perez-Vigil A, Fernandez de la Cruz L, Brander G, Isomura K, Gromark C, Mataix-Cols D. The link between autoimmune diseases and obsessive-compulsive and tic disorders: a systematic review. Neurosci Biobehav Rev. 2016;71:542-62. doi: 10.1016/j.neubiorev.2016.09.025.

64. Nielsen PR, Benros ME, Dalsgaard S. Associations Between autoimmune diseases and attention-deficit/ Hyperactivity disorder: a nationwide study. J Am Acad Child Adolesc Psychiatry. 2017;56(3):234-40.e1. doi: 10.1016/j. jaac.2016.12.010.

65. Mataix-Cols D, Frans E, Perez-Vigil A, Kuja-Halkola $\mathrm{R}$, Gromark C, Isomura $\mathrm{K}$, et al. A total-population multigenerational family clustering study of autoimmune diseases in obsessive-compulsive disorder and Tourette's/ chronic tic disorders. Mol Psychiatry. 2018;23(7):1652-8. doi: 10.1038/mp.2017.215.

66. Hounie AG, Pauls DL, do Rosario-Campos MC, Mercadante MT, Diniz JB, De Mathis MA, et al. Obsessive-compulsive spectrum disorders and rheumatic fever: a family study. Biol Psychiatry. 2007;61(3):266-72. doi: $10.1016 / \mathrm{j}$. biopsych.2006.02.021.

67. Shonkoff JP, Garner AS; Committee on Psychosocial Aspects of Child and Family Health; Committee on Early Childhood, Adoption, and Dependent Care; Section on Developmental and Behavioral Pediatrics. The lifelong effects of early childhood adversity and toxic stress. Pediatrics. 2012;129(1):e232-46. doi: 10.1542/peds.20112663.

68. Estes ML, McAllister AK. Maternal immune activation: Implications for neuropsychiatric disorders. Science. 2016;353(6301):772-7. doi: 10.1126/science.aag3194.

69. Hostinar CE, Nusslock R, Miller GE. Future directions in the study of early-life stress and physical and emotional health: implications of the neuroimmune network hypothesis. J Clin Child Adolesc Psychol. 2018;47(1):142-56. doi: 10.1080/15374416.2016.1266647.

70. Scheinost D, Sinha R, Cross SN, Kwon SH, Sze G, Constable RT, et al. Does prenatal stress alter the developing connectome? Pediatr Res. 2017;81(1-2):214-26. doi: 10.1038/ pr.2016.197.

71. Hantsoo L, Kornfield S, Anguera MC, Epperson CN. Inflammation: a proposed intermediary between maternal stress and offspring neuropsychiatric risk. Biol Psychiatry. 2019;85(2):97-106. doi: 10.1016/j.biopsych.2018.08.018.

72. Morgan CP, Chan JC, Bale TL. Driving the next generation: paternal lifetime experiences transmitted via extracellular vesicles and their small RNA cargo. Biol Psychiatry. 2019;85(2):164-71. doi: 10.1016/j.biopsych.2018.09.007.

73. Croen LA, Grether JK, Yoshida CK, Odouli R, Van de Water J. Maternal autoimmune diseases, asthma and allergies, and 
childhood autism spectrum disorders: a case-control study. Arch Pediatrics Adolesc Med. 2005;159(2):151-7. doi: 10.1001/archpedi.159.2.151.

74. Atladottir HO, Thorsen P, Ostergaard L, Schendel DE, Lemcke $\mathrm{S}$, Abdallah $\mathrm{M}$, et al. Maternal infection requiring hospitalization during pregnancy and autism spectrum disorders. J Autism Dev Disord. 2010;40(12):1423-30. doi: 10.1007/s10803-010-1006-y.

75. Class QA, Abel KM, Khashan AS, Rickert ME, Dalman $\mathrm{C}$, Larsson $\mathrm{H}$, et al. Offspring psychopathology following preconception, prenatal and postnatal maternal bereavement stress. Psychol Med. 2014;44(1):71-84. doi: 10.1017/ S0033291713000780.

76. Lyall K, Ashwood P, Van de Water J, Hertz-Picciotto I. Maternal immune-mediated conditions, autism spectrum disorders, and developmental delay. J Autism Dev Disord. 2014;44(7):1546-55. doi: 10.1007/s10803-013-2017-2.

77. Flinkkila E, Keski-Rahkonen A, Marttunen M, Raevuori A. Prenatal inflammation, infections and mental disorders. Psychopathology. 2016;49(5):317-33. doi: $10.1159 / 000448054$.

78. Zerbo O, Qian Y, Yoshida C, Grether JK, Van de Water J, Croen LA. Maternal infection during pregnancy and autism spectrum disorders. J Autism Dev Disord. 2015;45(12):401525. doi: 10.1007/s10803-013-2016-3.

79. Jiang HY, Xu LL, Shao L, Xia RM, Yu ZH, Ling ZX, et al. Maternal infection during pregnancy and risk of autism spectrum disorders: a systematic review and meta-analysis. Brain Behav Immun. 2016;58:165-72. doi: 10.1016/j. bbi.2016.06.005.

80. Hornig M, Bresnahan MA, Che X, Schultz AF, Ukaigwe JE, Eddy ML, et al. Prenatal fever and autism risk. Mol Psychiatry. 2018;23(3):759-66. doi: 10.1038/mp.2017.119.

81. Selten JP, Brown AS, Moons KG, Slaets JP, Susser ES, Kahn RS. Prenatal exposure to the 1957 influenza pandemic and non-affective psychosis in The Netherlands. Schizophr Res. 1999;38(2-3):85-91. https://doi.org/10.1016/S09209964(99)00005-5.

82. Brown AS, Schaefer CA, Wyatt RJ, Goetz R, Begg MD, Gorman JM, et al. Maternal exposure to respiratory infections and adult schizophrenia spectrum disorders: a prospective birth cohort study. Schizophr Bull. 2000;26(2):287-95. doi: 10.1093/oxfordjournals.schbul.a033453.

83. Ellman LM, Yolken RH, Buka SL, Torrey EF, Cannon TD. Cognitive functioning prior to the onset of psychosis: the role of fetal exposure to serologically determined influenza infection. Biol Psychiatry. 2009;65(12):1040-7. doi: 10.1016/j.biopsych.2008.12.015.

84. Nielsen PR, Laursen TM, Mortensen PB. Association between parental hospital-treated infection and the risk of schizophrenia in adolescence and early adulthood. Schizophr Bull. 2013;39(1):230-7. doi: 10.1093/schbul/sbr149.

85. Khandaker GM, Zimbron J, Lewis G, Jones PB. Prenatal maternal infection, neurodevelopment and adult schizophrenia: a systematic review of population-based studies. Psychol Med. 2013;43(2):239-57. doi: 10.1017/ S0033291712000736.

86. Brown AS, Susser ES, Lin SP, Neugebauer R, Gorman JM. Increased risk of affective disorders in males after second trimester prenatal exposure to the Dutch hunger winter of 1944-45. Brit J Psychiatry. 1995;166(5):601-6. doi: 10.1192/ bjp.166.5.601.

87. Brown AS, van Os J, Driessens C, Hoek HW, Susser ES. Further evidence of relation between prenatal famine and major affective disorder. Am J Psychiatry. 2000;157(2):190-5. doi: 10.1176/appi.ajp.157.2.190.

88. Khashan AS, McNamee R, Henriksen TB, Pedersen MG, Kenny LC, Abel KM, et al. Risk of affective disorders following prenatal exposure to severe life events: a Danish population-based cohort study. J Psychiatr Res. 2011;45(7):879-85. doi: 10.1016/j.jpsychires.2010.12.005.

89. Kleinhaus K, Harlap S, Perrin M, Manor O, MargalitCalderon R, Opler M, et al. Prenatal stress and affective disorders in a population birth cohort. Bipolar Disord. 2013;15(1):92-9. doi: 10.1111/bdi.12015.

90. Simanek AM, Meier HC. Association Between Prenatal Exposure to Maternal Infection and Offspring Mood Disorders: A Review of the Literature. Curr Probl Pediatr Adolesc Health Care. 2015;45(11):325-64. doi: 10.1016/j. cppeds.2015.06.008.

91. Goldstein JM, Holsen L, Huang G, Hammond BD, JamesTodd T, Cherkerzian S, et al. Prenatal stress-immune programming of sex differences in comorbidity of depression and obesity/metabolic syndrome. Dialogues Clin Neurosci. 2016;18(4):425-36. Available from: https://www.ncbi.nlm. nih.gov/pmc/articles/PMC5286728/.

92. Leff-Gelman P, Mancilla-Herrera I, Flores-Ramos M, CruzFuentes C, Reyes-Grajeda JP, Garcia-Cuetara Mdel P, et al. The immune system and the role of inflammation in perinatal depression. Neurosci Bull. 2016;32(4):398-420. doi: 10.1007/ s12264-016-0048-3.

93. Vasconcelos MS, Sampaio AS, Hounie AG, Akkerman F, Curi M, Lopes AC, et al. Prenatal, perinatal, and postnatal risk factors in obsessive-compulsive disorder. Biol Psychiatry. 2007;61(3):301-7. doi: 10.1016/j.biopsych.2006.07.014.

94. Geller DA, Wieland N, Carey K, Vivas F, Petty CR, Johnson $\mathrm{J}$, et al. Perinatal factors affecting expression of obsessive compulsive disorder in children and adolescents. J Child Adolesc Psychopharmacol. 2008;18(4):373-9. doi: 10.1089/ cap.2007.0112

95. Brander G, Rydell M, Kuja-Halkola R, Fernandez de la Cruz L, Lichtenstein P, Serlachius E, et al. Association of perinatal risk factors with obsessive-compulsive disorder: a population-based birth cohort, Sibling Control Study. JAMA Psychiatry. 2016;73(11):1135-44. doi: 10.1001/ jamapsychiatry.2016.2095.

96. Li J, Olsen J, Vestergaard M, Obel C. Attention-deficit/ hyperactivity disorder in the offspring following prenatal maternal bereavement: a nationwide follow-up study in Denmark. Eur Child Adolesc Psychiatry. 2010;19(10):74753. doi: 10.1007/s00787-010-0113-9.

97. Grizenko N, Fortier ME, Zadorozny C, Thakur G, Schmitz N, Duval R, et al. Maternal Stress during Pregnancy, ADHD Symptomatology in Children and Genotype: Gene-Environment Interaction. J Can Acad Child Adolesc Psychiatry. 2012 Feb;21(1):9-15. Available from: https:// www.ncbi.nlm.nih.gov/pmc/articles/PMC3269259/.

98. MacKinnon N, Kingsbury M, Mahedy L, Evans J, Colman I. The association between prenatal stress and externalizing symptoms in childhood: evidence from the Avon Longitudinal Study of Parents and Children. Biol Psychiatry. 2018;83(2):100-8. doi: 10.1016/j.biopsych.2017.07.010.

99. Chao TK, Hu J, Pringsheim T. Prenatal risk factors for Tourette syndrome: a systematic review. BMC Pregnancy Childbirth. 2014;14:53. doi: 10.1186/1471-2393-14-53.

100. Mathews CA, Scharf JM, Miller LL, Macdonald-Wallis C, Lawlor DA, Ben-Shlomo Y. Association between pre- and perinatal exposures and Tourette syndrome or chronic tic disorder in the ALSPAC cohort. Br J Psychiatry. 2014;204(1):40-5. doi: 10.1192/bjp.bp.112.125468. 
101. Browne HA, Modabbernia A, Buxbaum JD, Hansen SN, Schendel DE, Parner ET, et al. Prenatal maternal smoking and increased risk for Tourette syndrome and chronic Tic disorders. J Am Acad Child Adolesc Psychiatry. 2016;55(9):784-91. doi: 10.1016/j.jaac.2016.06.010.

102. Abdulkadir M, Tischfield JA, King RA, Fernandez TV, Brown LW, Cheon KA, et al. Pre- and perinatal complications in relation to Tourette syndrome and co-occurring obsessivecompulsive disorder and attention-deficit/hyperactivity disorder. J Psychiatr Res. 2016;82:126-35. doi: 10.1016/j. jpsychires.2016.07.017.

103. Wang C, Geng H, Liu W, Zhang G. Prenatal, perinatal, and postnatal factors associated with autism: a meta-analysis. Medicine (Baltimore). 2017;96(18):e6696. doi: 10.1097/ MD.0000000000006696.

104. Muhle RA, Reed HE, Stratigos KA, Veenstra-VanderWeele $\mathrm{J}$. The emerging clinical neuroscience of autism spectrum disorder: a review. JAMA Psychiatry. 2018;75(5):514-23. doi: 10.1001/jamapsychiatry.2017.4685.

105. Beversdorf DQ, Manning SE, Hillier A, Anderson SL, Nordgren RE, Walters SE, et al. Timing of prenatal stressors and autism. J Autism Dev Disord. 2005;35(4):471-8. doi: 10.1007/s10803-005-5037-8.

106. Careaga M, Murai T, Bauman MD. Maternal immune activation and autism spectrum disorder: from rodents to nonhuman and human primates. Biol Psychiatry. 2017;81(5):391-401. doi: 10.1016/j.biopsych.2016.10.020.

107. Perrone-McGovern K, Simon-Dack S, Niccolai L. Prenatal and perinatal factors related to autism, IQ, and adaptive functioning. J Genet Psychol. 2015;176(1-2):1-10. doi: 10.1080/00221325.2014.987201.

108. Meltzer A, Van de Water J. The role of the immune system in autism spectrum disorder. Neuropsychopharmacology. 2017;42(1):284-98. doi: 10.1038/npp.2016.158.

109. Stoner R, Chow ML, Boyle MP, Sunkin SM, Mouton PR, Roy S, et al. Patches of disorganization in the neocortex of children with autism. N Engl J Med. 2014;370(13):1209-19. doi: 10.1056/NEJMoa1307491.

110. Hecht PM, Hudson M, Connors SL, Tilley MR, Liu X, Beversdorf DQ. Maternal serotonin transporter genotype affects risk for ASD with exposure to prenatal stress. Autism Res. 2016;9(11):1151-60. doi: 10.1002/aur.1629.

111. Knuesel I, Chicha L, Britschgi M, Schobel SA, Bodmer M, Hellings JA, et al. Maternal immune activation and abnormal brain development across CNS disorders. Nat Rev Neurol. 2014;10(11):643-60. doi: 10.1038/nrneurol.2014.187.

112. Croen LA, Qian Y, Ashwood P, Daniels JL, Fallin D, Schendel D, et al. Family history of immune conditions and autism spectrum and developmental disorders: Findings from the study to explore early development. Autism Res. 2019;12(1):123-35. doi: 10.1002/aur.1979.

113. Wu S, Ding Y, Wu F, Li R, Xie G, Hou J, et al. Family history of autoimmune diseases is associated with an increased risk of autism in children: a systematic review and meta-analysis. Neurosci Biobehav Rev. 2015;55:322-32. doi: 10.1016/j. neubiorev.2015.05.004.

114. Xu G, Snetselaar LG, Jing J, Liu B, Strathearn L, Bao W. Association of food allergy and other allergic conditions with autism spectrum disorder in children. JAMA Netw Open. 2018;1(2):e180279. doi: 10.1001/ jamanetworkopen.2018.0279.

115. McDougle CJ. Another step toward defining an immune-mediated subtype of autism spectrum disorder. JAMA Netw Open. 2018;1(2):e180280. doi: 10.1001/ jamanetworkopen.2018.0280.
116. Ashwood P, Krakowiak P, Hertz-Picciotto I, Hansen R, Pessah I, Van de Water J. Elevated plasma cytokines in autism spectrum disorders provide evidence of immune dysfunction and are associated with impaired behavioral outcome. Brain Behav Immun. 2011;25(1):40-5. doi: 10.1016/j.bbi.2010.08.003.

117. Tobiasova Z, van der Lingen KH, Scahill L, Leckman JF, Zhang Y, Chae W, et al. Risperidone-related improvement of irritability in children with autism is not associated with changes in serum of epidermal growth factor and interleukin-13. J Child Adolesc Psychopharmacol. 2011;21(6):555-64. doi: 10.1089/cap.2010.0134.

118. Ricci S, Businaro R, Ippoliti F, Lo Vasco VR, Massoni F, Onofri E, et al. Altered cytokine and BDNF levels in autism spectrum disorder. Neurotoxicity research. 2013;24(4):491501.

119. Napolioni V, Ober-Reynolds B, Szelinger S, Corneveaux JJ, Pawlowski T, Ober-Reynolds S, et al. Plasma cytokine profiling in sibling pairs discordant for autism spectrum disorder. J Neuroinflammation. 2013;10:38. doi: 10.1186/1742-2094-10-38.

120. Masi A, Quintana DS, Glozier N, Lloyd AR, Hickie IB, Guastella AJ. Cytokine aberrations in autism spectrum disorder: a systematic review and meta-analysis. Mol Psychiatry. 2015;20(4):440-6. doi: 10.1038/mp.2014.59.

121. Pardo CA, Farmer CA, Thurm A, Shebl FM, Ilieva J, Kalra $\mathrm{S}$, et al. Serum and cerebrospinal fluid immune mediators in children with autistic disorder: a longitudinal study. Mol Autism. 2017;8:1. doi: 10.1186/s13229-016-0115-7.

122. Krakowiak P, Goines PE, Tancredi DJ, Ashwood P, Hansen RL, Hertz-Picciotto I, et al. Neonatal cytokine profiles associated with autism spectrum disorder. Biol Psychiatry. 2017;81(5):442-51. doi: 10.1016/j.biopsych.2015.08.007.

123. Radhakrishnan RG, Meltzer HY, Bobo WV, Heckers SH, Fatemi HS, D'Souza DC. Schizophrenia. Current diagnosis \& treatment psychiatry. 3rd ed. New York: McGraw-Hill Education; 2019. p.207-35.

124. Forsyth JK, Ellman LM, Tanskanen A, Mustonen U, Huttunen MO, Suvisaari J, et al. Genetic risk for schizophrenia, obstetric complications, and adolescent school outcome: evidence for gene-environment interaction. Schizophr Bull. 2013;39(5):1067-76. doi: 10.1093/schbul/ sbs098.

125. Simoila L, Isometsa E, Gissler M, Suvisaari J, Halmesmaki E, Lindberg N. Obstetric and perinatal health outcomes related to schizophrenia: a national register-based follow-up study among finnish women born between 1965 and 1980 and their offspring. Eur Psychiatry. 2018;52:68-75. doi: 10.1016/j.eurpsy.2018.04.001.

126. Pugliese V, Bruni A, Carbone EA, Calabro G, Cerminara G, Sampogna G, et al. Maternal stress, prenatal medical illnesses and obstetric complications: risk factors for schizophrenia spectrum disorder, bipolar disorder and major depressive disorder. Psychiatry Res. 2018;271:23-30. doi: 10.1016/j.psychres.2018.11.023.

127. Benros ME, Eaton WW, Mortensen PB. The epidemiologic evidence linking autoimmune diseases and psychosis. Biol Psychiatry. 2014;75(4):300-6. doi: 10.1016/j. biopsych.2013.09.023.

128. Benros ME, Nielsen PR, Nordentoft M, Eaton WW, Dalton SO, Mortensen PB. Autoimmune diseases and severe infections as risk factors for schizophrenia: a 30-year population-based register study. Am J Psychiatry. 2011;168(12):1303-10. doi: 10.1176/appi. ajp.2011.11030516. 
129. Karakula-Juchnowicz H, Dzikowski M, Pelczarska A, Dzikowska I, Juchnowicz D. The brain-gut axis dysfunctions and hypersensitivity to food antigens in the etiopathogenesis of schizophrenia. Psychiatr Pol. 2016;50(4):747-60. doi: 10.12740/PP/OnlineFirst/45053.

130. Macul PF, Szejko N, do Rosário MC, Polga N, Requena GL. Risk Factors for Obsessive-Compulsive Symptoms. Follow-up of a community-based youth cohort. JACAPP. 2019 (submitted).

131. Martino D, Zis P, Buttiglione M. The role of immune mechanisms in Tourette syndrome. Brain Res. 2015;1617:126-43. doi: 10.1016/j.brainres.2014.04.027.

132. Walls A, Cubangbang M, Wang H, Raiji M, Knight J, Steehler M, et al. Pediatric Autoimmune Neuropsychiatric Disorder Associated with Streptococcus Immunology: a pilot study. Otolaryngol Head Neck Surg. 2015;153(1):1306. doi: 10.1177/0194599815577784.

133. Rodriguez N, Morer A, Gonzalez-Navarro EA, Serra-Pages C, Boloc D, Torres T, et al. Inflammatory dysregulation of monocytes in pediatric patients with obsessive-compulsive disorder. J Neuroinflammation. 2017;14(1):261. doi: 10.1186/s12974-017-1042-z.

134. Lamothe H, Baleyte JM, Smith P, Pelissolo A, Mallet L. Individualized immunological data for precise classification of OCD patients. Brain Sci. 2018;8(8):pii: E149. doi: 10.3390/brainsci8080149.

135. Verlaet AAJ, Breynaert A, Ceulemans B, De Bruyne T, Fransen E, Pieters L, et al. Oxidative stress and immune aberrancies in attention-deficit/hyperactivity disorder (ADHD): a case-control comparison. Eur Child Adolesc Psychiatry. 28(5):719-29. doi: 10.1007/s00787-018-1239-4.

136. Lloyd-Price J, Mahurkar A, Rahnavard G, Crabtree J, Orvis J, Hall AB, et al. Strains, functions and dynamics in the expanded Human Microbiome Project. Nature. 2017;550(7674):61-6. doi: 10.1038/nature23889.

137. Sender R, Fuchs S, Milo R. Are we really vastly outnumbered? Revisiting the ratio of bacterial to host cells in humans. Cell. 2016;164(3):337-40. doi: 10.1016/j. cell.2016.01.013

138. Warner BB. The contribution of the gut microbiome to neurodevelopment and neuropsychiatric disorders. Pediatr Res. 2018; 85(2):216-24. doi: 10.1038/s41390-018-0191-9.

139. Abdel-Haq R, Schlachetzki JCM, Glass CK, Mazmanian SK. Microbiome-microglia connections via the gutbrain axis. J Exp Med. 2019;216(1):41-59. doi: 10.1084/ jem.20180794.

140. DeCapo M, Thompson JR, Dunn G, Sullivan EL. Perinatal nutrition and programmed risk for neuropsychiatric disorders: a focus on animal models. Biol Psychiatry. 2019;85(2):122-34. doi: 10.1016/j.biopsych.2018.08.006.

141. Lindsay KL, Buss C, Wadhwa PD, Entringer S. The interplay between nutrition and stress in pregnancy: implications for fetal programming of brain development. Biol Psychiatry. 2019;85(2):135-49. doi: 10.1016/j.biopsych.2018.06.021.

142. Vuong HE, Hsiao EY. Emerging roles for the gut microbiome in autism spectrum disorder. Biol Psychiatry. 2017;81(5):411-23. doi: 10.1016/j.biopsych.2016.08.024.

143. Schwarz E, Maukonen J, Hyytiainen T, Kieseppa T, Oresic M, Sabunciyan S, et al. Analysis of microbiota in first episode psychosis identifies preliminary associations with symptom severity and treatment response. Schizophr Res. 2018;192:398-403. doi: 10.1016/j.schres.2017.04.017.

144. Kang DW, Adams JB, Gregory AC, Borody T, Chittick L, Fasano A, et al. Microbiota Transfer Therapy alters gut ecosystem and improves gastrointestinal and autism symptoms: an open-label study. Microbiome. 2017;5(1):10. doi: 10.1186/s40168-016-0225-7.

145. Castro-Nallar E, Bendall ML, Perez-Losada M, Sabuncyan S, Severance EG, Dickerson FB, et al. Composition, taxonomy and functional diversity of the oropharynx microbiome in individuals with schizophrenia and controls. Peer J. 2015;3:e1140. doi: 10.7717/peerj.1140. eCollection 2015.

146. Yolken RH, Severance EG, Sabunciyan S, Gressitt KL, Chen O, Stallings C, et al. Metagenomic sequencing indicates that the oropharyngeal phageome of individuals with schizophrenia differs from that of controls. Schizophr Bull. 2015;41(5):1153-61. doi: 10.1093/schbul/sbu197.

147. Dickerson F, Severance E, Yolken R. The microbiome, immunity, and schizophrenia and bipolar disorder. Brain Behav Immun. 2017;62:46-52. doi: 10.1016/j. bbi.2016.12.010.

148. Cuomo A, Maina G, Rosso G, Beccarini Crescenzi B, Bolognesi S, Di Muro A, et al. The Microbiome: A New Target for Research and Treatment of Schizophrenia and its Resistant Presentations? A systematic literature search and review. Front Pharmacol. 2018;9:1040. doi: 10.3389/ fphar.2018.01040.

149. Kanji S, Fonseka TM, Marshe VS, Sriretnakumar V, Hahn MK, Muller DJ. The microbiome-gut-brain axis: implications for schizophrenia and antipsychotic induced weight gain. Eur Arch Psychiatry Clin Neurosci. 2018;268(1):3-15. doi: 10.1007/s00406-017-0820-z.

150. Shen Y, Xu J, Li Z, Huang Y, Yuan Y, Wang J, et al. Analysis of gut microbiota diversity and auxiliary diagnosis as a biomarker in patients with schizophrenia: a cross-sectional study. Schizophr Res. 2018; pii: S0920-9964(18)30002-1. doi: 10.1016/j.schres.2018.01.002.

151. Turna J, Grosman Kaplan K, Anglin R, Van Ameringen M. "What's bugging the gut in ocd?" a review of the gut microbiome in obsessive-compulsive disorder. Depress Anxiety. 2016;33(3):171-8. doi: 10.1002/da.22454.

152. Zhao H, Shi Y, Luo X, Peng L, Yang Y, Zou L. The effect of fecal microbiota transplantation on a child with Tourette syndrome. Case Rep Med. 2017;2017:6165239. doi: $10.1155 / 2017 / 6165239$.

153. Quagliariello A, Del Chierico F, Russo A, Reddel S, Conte $\mathrm{G}$, Lopetuso LR, et al. Gut microbiota profiling and gutbrain crosstalk in children affected by pediatric acute-onset neuropsychiatric syndrome and pediatric autoimmune neuropsychiatric disorders associated with streptococcal infections. Front Microbiol. 2018;9:675. doi: 10.3389/ fmicb.2018.00675.

154. Horne R, Foster JA. Metabolic and microbiota measures as peripheral biomarkers in major depressive disorder. Front Psychiatry. 2018;9:513. doi: 10.3389/fpsyt.2018.00513.

155. Winter G, Hart RA, Charlesworth RPG, Sharpley CF. Gut microbiome and depression: what we know and what we need to know. Rev Neurosci. 2018;29(6):629-43. doi: 10.1515/revneuro-2017-0072.

156. Temko JE, Bouhlal S, Farokhnia M, Lee MR, Cryan JF, Leggio L. The microbiota, the gut and the brain in eating and alcohol use disorders: a 'menage a trois'? Alcohol Alcohol. 2017;52(4):403-13. doi: 10.1093/alcalc/agx024.

157. Kim S, Jazwinski SM. The gut microbiota and healthy aging: a mini-review. Gerontology. 2018;64(6):513-20. doi: 10.1159/000490615.

158. Collins SM, Surette M, Bercik P. The interplay between 
the intestinal microbiota and the brain. Nat Rev Microbiol. 2012;10(11):735-42. doi: 10.1038/nrmicro2876.

159. Petra AI, Panagiotidou S, Hatziagelaki E, Stewart JM, Conti P, Theoharides TC. Gut-Microbiota-Brain Axis and Its Effect on Neuropsychiatric Disorders With Suspected Immune Dysregulation. Clin Ther. 2015;37(5):984-95. doi: 10.1016/j.clinthera.2015.04.002.

160. Dinan TG, Cryan JF. The impact of gut microbiota on brain and behaviour: implications for psychiatry. Curr Opin Clin Nutr Metab Care. 2015;18(6):552-8. doi: 10.1097/ MCO.0000000000000221.

161. Brett BE, de Weerth C. The microbiota-gut-brain axis: a promising avenue to foster healthy developmental outcomes. Dev Psychobiol. 2019;61(5):772-782. doi: 10.1002/dev.21824.

162. Vuong HE, Yano JM, Fung TC, Hsiao EY. The microbiome and host behavior. Annu Rev Neurosci. 2017;40:21-49. doi: 10.1146/annurev-neuro-072116-031347.

163. Buffington SA, Di Prisco GV, Auchtung TA, Ajami NJ, Petrosino JF, Costa-Mattioli M. Microbial reconstitution reverses maternal diet-induced social and synaptic deficits in offspring. Cell. 2016;165(7):1762-75. doi: 10.1016/j. cell.2016.06.001

164. Degroote S, Hunting DJ, Baccarelli AA, Takser L. Maternal gut and fetal brain connection: Increased anxiety and reduced social interactions in Wistar rat offspring following peri-conceptional antibiotic exposure. Prog Neuropsychopharmacol Biol Psychiatry. 2016;71:76-82. doi: 10.1016/j.pnpbp.2016.06.010.

165. Zijlmans MA, Korpela K, Riksen-Walraven JM, de Vos WM, de Weerth C. Maternal prenatal stress is associated with the infant intestinal microbiota. Psychoneuroendocrinology. 2015a;53:233-45. doi: 10.1016/j.psyneuen.2015.01.006.

166. Zijlmans MA, Riksen-Walraven JM, de Weerth C. Associations between maternal prenatal cortisol concentrations and child outcomes: a systematic review. Neurosci Biobehav Rev. 2015b;53:1-24. doi: 10.1016/j. neubiorev.2015.02.015.

167. Roberts RC, Farmer CB, Walker CK. The human brain microbiome; there are bacteria in our brains! In: 2018 Neuroscience Meeting Planner. San Diego: Society for Neuroscience; 2018. Abstr. No. 594.08/YY23. Available from: https://abstractsonline.com/pp8/\#!/4649/ presentation $/ 32057$.

168. Clancy B, Finlay BL, Darlington RB, Anand KJ. Extrapolating brain development from experimental species to humans. Neurotoxicology. 2007;28(5):931-7. doi: 10.1016/j.neuro.2007.01.014.

169. Cao M, Cortes M, Moore CS, Leong SY, Durosier LD, Burns $\mathrm{P}$, et al. Fetal microglial phenotype in vitro carries memory of prior in vivo exposure to inflammation. Front Cell Neurosci. 2015;9:294. doi: 10.3389/fncel.2015.00294.

170. Gumusoglu SB, Stevens HE. Maternal inflammation and neurodevelopmental programming: a review of preclinical outcomes and implications for translational psychiatry. Biol Psychiatry. 2019;85(2):107-21. doi: 10.1016/j. biopsych.2018.08.008.

171. Paolicelli RC, Ferretti MT. Function and dysfunction of microglia during brain development: consequences for synapses and neural circuits. Front Synaptic Neurosci. 2017;9:9. doi: 10.3389/fnsyn.2017.00009.
172. Hammond TR, Dufort C, Dissing-Olesen L, Giera S, Young A, Wysoker A, et al. Single-cell RNA sequencing of microglia throughout the mouse lifespan and in the injured brain reveals complex cell-state changes. Immunity. 2019;50(1):253-71.e6. doi: 10.1016/j.immuni.2018.11.004.

173. Schaafsma W, Basterra LB, Jacobs S, Brouwer N, Meerlo P, Schaafsma A, et al. Maternal inflammation induces immune activation of fetal microglia and leads to disrupted microglia immune responses, behavior, and learning performance in adulthood. Neurobiol Dis. 2017;106:291-300. doi: 10.1016/j.nbd.2017.07.017

174. Hutton LC, Castillo-Melendez M, Smythe GA, Walker DW. Microglial activation, macrophage infiltration, and evidence of cell death in the fetal brain after uteroplacental administration of lipopolysaccharide in sheep in late gestation. Am J Obst Gynecol. 2008;198(1):117.e1-11. doi: 10.1016/j.ajog.2007.06.035.

175. Meyer U, Nyffeler M, Engler A, Urwyler A, Schedlowski $\mathrm{M}$, Knuesel I, et al. The time of prenatal immune challenge determines the specificity of inflammation-mediated brain and behavioral pathology. J Neurosci. 2006;26(18):4752-62. doi: 10.1523/JNEUROSCI.0099-06.2006.

176. Onore CE, Schwartzer JJ, Careaga M, Berman RF, Ashwood P. Maternal immune activation leads to activated inflammatory macrophages in offspring. Brain Behav Immun. 2014;38:220-6. doi: 10.1016/j.bbi.2014.02.007.

177. Rice D, Barone S Jr. Critical periods of vulnerability for the developing nervous system: evidence from humans and animal models. Environ Health Perspect. 2000;108(Suppl 3):511-33. doi: 10.1289/ehp.00108s3511.

178. Levin SG, Godukhin OV. Modulating effect of cytokines on mechanisms of synaptic plasticity in the brain. Biochemistry (Mosc). 2017;82(3):264-74. doi: 10.1134/ S000629791703004X.

179. van Steenwyk G, Roszkowski M, Manuella F, Franklin TB, Mansuy IM. Transgenerational inheritance of behavioral and metabolic effects of paternal exposure to traumatic stress in early postnatal life: evidence in the 4th generation. Environ Epigenet. 2018;4(2):dvy023. doi: 10.1093/eep/ dvy023.

180. Vaughan OR, Rosario FJ, Powell TL, Jansson T. Regulation of placental amino acid transport and fetal growth. Progr Mol Biol Transl Sci. 2017;145:217-51. doi: 10.1016/ bs.pmbts.2016.12.008.

181. Robertson MM, Eapen V, Singer HS, Martino D, Scharf JM, Paschou P, et al. Gilles de la Tourette syndrome. Nat Rev Dis Primers. 2017;3:16097. doi: 10.1038/nrdp.2016.97.

182. Swedo SE, Frankovich J, Murphy TK. Overview of treatment of pediatric acute-onset neuropsychiatric syndrome. J Child Adolesc Psychopharmacol. 2017;27(7):562-5. doi: 10.1089/ cap.2017.0042.

183. Gladysz D, Krzywdzinska A, Hozyasz KK. Immune abnormalities in autism spectrum disorder-could they hold promise for causative treatment? Mol Neurobiol. 2018;55(8):6387-435. doi: 10.1007/s12035-017-0822-x.

184. Pfau ML, Menard C, Russo SJ. Inflammatory mediators in mood disorders: therapeutic opportunities. Annu Rev Pharmacol Toxicol. 2018;58:411-28. doi: 10.1146/annurevpharmtox-010617-052823.

Received: April 24, 2019

Accept: June 6, 2019 